\title{
Factors Influencing Consumer's Decision to Purchase Fresh Potatoes in Malaysia
}

N. Chamhuri

National University of Malaysia

Bangi, Malaysia
P.J. Batt

Curtin University

Perth, Australia

Key words: potatoes, fresh produce, vegetable marketing, consumers, Malaysia

\begin{abstract}
Freshness, size and price were the most frequently cited variables in respondents' decision to purchase fresh potatoes. Principal component analysis subsequently identified five constructs which were found to influence respondents' decision to purchase: value, physical appearance, usage, prior experience and promotion.
\end{abstract}

\section{INTRODUCTION}

The vegetable industry in Malaysia is comprised of a diverse group of crops, with more than 50 different types of vegetables cultivated for both fresh consumption and processing. Nevertheless, the industry can be described as small and fragmented (Chong, 2007). In 2010, in Peninsular Malaysia (not including Sabah and Sarawak), only 18,873 hectares were planted in vegetable crops compared to other crops such as palm oil (3,005,035 ha), rubber (1,226,534 ha) and paddy (324,566 ha) (Ministry of Agriculture and Agro-Based Industry, 2012).

Due to the hot climate, Malaysia mainly grows tropical vegetables such as mustard, cucumber, spinach, chilli and long beans (Malaysia, 2011). Temperate vegetables such as potatoes are normally imported into the country from Australia, China, India, Indonesia and New Zealand (Ministry of Agriculture and Agro-Based Industry, 2012; Rahim, 2007).

With the growth and expansion of modern retail formats, the rise in personal disposal income, changes in lifestyle and an increasing awareness of food safety, consumers in Malaysia are faced with multiple quality attributes upon which they can make their decision to purchase fresh potatoes. This paper seeks to identify those quality attributes that are most important in the consumers' decision to purchase fresh potatoes.

\section{PERCEIVED QUALITY MODEL}

In this research, the term perceived quality was used to describe consumers' quality judgements. These are built on the consumers' perceptions, needs and objectives. The conceptual framework for this study was adapted from Steenkamp (1990).

Steenkamp (1990) focused on the theoretical concepts of food quality and value. Value was related to perceived quality through three dimensions: preference, subjectobject interaction and the consumption experience. Perceived quality is a higher-level abstraction based on the quality attributes of the product. However, it is important to understand how much importance consumers place on each of these quality attributes. For this reason it is necessary to understand and to differentiate between the concept of quality cues and quality attributes. 
Quality cues are defined as information stimuli that are related to the quality of the product and can be ascertained by the consumer through the senses prior to consumption (Steenkamp, 1990 p.312). How the cues are gathered and categorised are based upon the beliefs and prior knowledge of the product that consumers have experienced.

\section{Intrinsic cues}

The concept of intrinsic and extrinsic cues was developed by Olson and Jacoby (1972). Intrinsic cues describe the physical attributes of the product, which cannot be changed or manipulated without changing the product itself (Grunert, 2005). Intrinsic cues comprise both search and experience attributes. Consumers may be able to judge search attributes such as appearance, colour, shape, size and structure immediately when doing their food shopping. Conversely, consumers can only evaluate the experience attributes such as taste, tenderness, crunchiness and juiciness after consuming the product. According to Ragaert et al. (2004), in the buying process, search attributes were found to be significantly more important.

Freshness is often cited as one of the most influential intrinsic cues impacting on the consumers' decision to purchase fresh vegetables (Toivonen and Brumell, 2008). Indicators of freshness vary across the different types of vegetables. In the case of potatoes, the physical appearance of the produce was described by the skin colour, texture, size and shape (Batt, 2009). Cleanliness (without soil) was also frequently cited by respondents in their decision to purchase potatoes. Von Alvensleben and Meier (1990), state quite emphatically that when purchasing fresh produce, 'consumers buy with their eyes'.

\section{Extrinsic cues}

According to Oude Ophuis and Van Trijp (1995), extrinsic cues are quality cues that are not related to the physical product, but become an important indicator of quality when comparing between two or more products that are similar in appearance. Olson (1977) mentioned that in situations when consumers cannot obtain enough information, price often substitutes for quality. According to Pride et al. (2004), price is a tool which informs consumers about the value of the product. Consumers often perceive that products with a higher price are of higher quality (Oude Ophuis and Van Trijp, 1995).

According to van der Pol and Ryan (1996), consumers seek the highest quality fresh produce at a lowest possible price. As reported by the Nielsen Shopper Trends Survey (Ng, 2011), Malaysian consumers are very price sensitive. Nevertheless, there are consumers who may be willing to pay more to obtain better quality food.

\section{Implicit cues}

These are derived from consumers' perception that the food they are about to consume is safe (Peri, 2006). Similarly, Keast (2009) found that food safety is an implicit part of food quality, given that safety is what consumers expect when they purchase food.

Food safety requirements for fresh produce are important compared to other types of agricultural products (Martinez and Poole, 2004). Although the presence of microbial contaminants is a serious threat to human health, consumers cannot detect the presence of viruses, bacteria and parasites in or on the fresh produce they purchase. The extensive use of agrochemicals can also constitute a food safety risk, for studies in Asia have repeatedly demonstrated that the usage of these agrochemicals is seldom in accordance with label recommendations (Shepherd, 2006). 


\section{METHODOLOGY}

For this study, the survey method was used for data collection. The survey method requires the development of a structured questionnaire given to a sample of a population which is designed to elicit specific information from respondents (Malhotra et al., 2008). Tull and Hawkins (1990) note that the survey method can provide data on attitudes, feelings, beliefs, past and intended behaviours, knowledge and personal characteristics. Furthermore, the survey method is the most common method of primary data collection in marketing research. It is simple to administer and provides reliable data where responses are limited to stated alternatives (Malhotra et al., 2008).

As the survey instrument for this study was quite large and involved 20 to 30 minutes of the respondents' time to complete, the researcher considered personal face-toface interviews to be the most appropriate means of data collection. Central location personal interviews, based on selected shopping malls and traditional markets, were considered to provide the most appropriate means of data collection. According to Hair (2008), the shopping mall intercept method is less expensive and more convenient because the researcher does not need to spend much time or effort to secure a person's willingness to participate in the interview, because both are already at a common location. Potential respondents are intercepted and interviewed as they arrive or as they are about to leave the shopping precinct.

The questionnaires were designed using a combination of both closed and openended questions. For the structured questions, a variety of alternative measures were utilised including multiple-choice, dichotomous and scale questions. For the unstructured questions, respondents were allowed to freely convey their views with regards to the topic of interest. Unstructured questions assist the researcher in obtaining a greater understanding of the topic, while also ensuring that no major variables were excluded from the fixed response question sets.

\section{RESULTS AND DISCUSSION}

Some $31 \%$ of respondents purchased fresh potatoes one time every two weeks, followed by one time per month (29\%) and one time per week $(24 \%)$ (Table 1). Only a few respondents purchased fresh potatoes two to three times in a week $(4 \%)$.

More than one half of the respondents (58\%) cited freshness as the most important criteria they considered in their decision to purchase fresh potatoes (Table 2). Other variables utilised by respondents in their decision to purchase fresh potatoes were size $(41 \%)$, price $(40 \%)$, cleanliness $(34 \%)$, texture $(30 \%)$ and skin colour $(28 \%)$. Freshness was described by the product appearance such as texture (Batt, 2004), size (Berdegue et al., 2003; Batt, 2004) and shape (Novotorova and Mazzocco, 2008; Batt, 2009). These findings suggest that consumers use these intrinsic quality cues as search attributes in their decision to purchase.

As Malaysian consumers are very price sensitive, price was frequently cited by respondents as influencing their decision to purchase fresh potatoes from a retail store. Since potatoes were imported, the cost of potatoes varied according to the origin of the crop. Due to the high demand for potatoes in Malaysia, about $70 \%$ of Indonesia's potato exports are destined for Malaysia (Adiyoga et al., 2001). Most Asian grown potatoes are valued for their versatility ("One potato, two potatoes", 2006).

Cleanliness was also related to the physical appearance of the tubers and was considered particularly important in the decision to purchase fresh potatoes. Cleanliness 
of the produce indicated that consumers preferred to purchase product that had been washed (Batt, 2009) and was free from soil (Fernqvist and Ekelund, 2009).

The physical appearance of the potatoes (freshness, firmness, freedom from pests and diseases, the absence of sprouts, skin colour and tuber size), food safety concerns (potatoes grown without chemical residues) and value (value for money, intended use and competitive price) were found to be the most important variables influencing the respondents' decision to purchase fresh potatoes (Table 3). The promotion of fresh potatoes through newspapers and catalogues was the least important variable respondents considered in purchasing fresh potatoes.

Principal component analysis, with varimax rotation and Kaiser normalisation, revealed five factors that collectively explained $68 \%$ of the variance (Table 4).

Factor One, with an Eigenvalue of 7.51, included five variables that accounted for $18 \%$ of the variance. This factor was labelled as "promotions" as it included variables such as advertising in newspaper catalogues, advice from sales assistants, packaging, product information in-store and labelling. Although the Cronbach's alpha for this factor was 0.89 , indicative of a high reliability, respondents considered this construct to be the least important in their decision to purchase fresh potatoes.

Factor Two, with an Eigenvalue of 2.49, had five variables that accounted for $15 \%$ of the variance. This construct, which was labelled as "prior experience", contained a diverse range of variables that were found to influence respondents' decision to purchase fresh potatoes such as organic, favourable prior purchase, where the potatoes were grown and variety. The Cronbach's alpha for this construct was 0.84 , but again, it was of only some importance in the respondents' decision to purchase fresh potatoes.

Factor Three had an Eigenvalue of 1.30 and explained 13\% of the variance. With a Cronbach's alpha of 0.79 , not only was the variable considered reliable, but it was considered to be among the most important factors influencing respondents' decision to purchase fresh potatoes. The variables which loaded onto this factor included tuber size, tuber shape, freedom from sprouting and flesh colour, and was labelled as "physical appearance".

Factor Four, with an Eigenvalue of 1.16, was comprised of three variables (competitive price, value for money and intended use) and was labelled as "value". This factor accounted for $11 \%$ of the variance and had a Cronbach's alpha of 0.79 . This construct was also considered to be one of the most important in the respondents' decision to purchase fresh potatoes from a retail store.

Factor Five, which was labelled as "usage", included three variables that facilitated the use of potatoes in the home (washed, skin colour and freedom from soil). This final factor accounted for $11 \%$ of the variance. Not only was this factor considered reliable (Cronbach's alpha of 0.76), but it was one of the most important in the respondents' decision to purchase fresh potatoes.

These findings were compared to Batt (2009), where five constructs were also identified as influencing Australian consumers' decision to purchase fresh potatoes. However, the importance attributed to each category was very different between Australian and Malaysian consumers. While Malaysian consumers perceived value as being the most important factor when purchasing fresh potatoes, Australian consumers emphasised the importance of freedom from pests and diseases, no sprouting, freshness and firmness.

Price and value was the second most important variable for Australian consumers in making their decision to purchase fresh potatoes. Somewhat unexpectedly, issues 
surrounding food safety such as freedom from chemical residues and freedom from pests and diseases were found to be of little importance to Malaysian consumers when purchasing fresh potatoes from a retail store. This result however, was similar to the findings of Jemison et al. (2008), where consumers in the USA ranked source and skin quality as the most important characteristics when purchasing fresh potatoes. This was followed by size, skin colour, flesh colour, variety and cleanliness. Price and organic were the third group of variables ranked by respondents as having some impact on the purchase of fresh potatoes. If consumers were concerned with the usage of chemicals in the production of potatoes, organic would have a higher ranking.

\section{CONCLUSIONS}

This paper provides valuable information for marketers to understand the behaviour of Malaysian consumers when purchasing fresh potatoes. The outcome of this research may assist retailers by providing new insights into the consumers' perceptions of food quality. Although much of the literature has focused on how to produce quality food, from a business perspective, to improve quality in the food industry, more attention must be directed towards gaining a greater understanding as to how consumers perceive quality. Ultimately, consumers are the ones who decide the quality they want and expect in the food that they consume.

\section{Literature Cited}

Adiyoga, W., Fuglie, K.O. and Suherman, R. 2001. Potato marketing in North Sumatra and an assessment of Indonesia potato trade. International Potato Center (CIP), Bogor, Indonesia: 104-110.

Batt, P.J. 2004. Consumer sovereignty: Exploring consumer needs. In: G.I. Johnson and P.J. Hofman (Eds). Agriproduct supply chain management in developing countries. Proceedings of a workshop held in Bali, Indonesia 19-22 August. ACIAR Proceedings 119: 77-87.

Batt, P.J. 2009. Factors influencing the purchase of fresh potatoes in retail stores in Perth, Western Australia. Acta Horticulturae 831: 169-178.

Berdegue, J.A. , Balsevich, F., Flores, L. and Reardon, T. 2003. The rise of supermarkets in Central America: Implications for private standards for quality and safety of fresh fruits and vegetables. Final report for USAID-RAISE/SPS Project. July.

Chong, E.F. 2007. The Malaysian vegetable industry. In F.M. Arshad, N.R. Abdullah, B. Kaur and A.M. Abdullah (Eds.), 50 Years of Malaysian Agriculture: Transformational Issues and Challenges. University Putra Malaysia Press: 337-358.

Fernqvist, F. and Ekelund, L. 2009. Consumer attitudes to potatoes and possible differentiation paths of the commodity. Acta Horticulturae 831: 313-318.

Grunert. K.G. 2005. Food quality and safety: Consumer perception and demand. European Review of Agricultural Economics. 32(3): 369-391.

Hair, J.F. 2008. Marketing research. North Ryde, NSW: McGraw-Hill Australia.

Jemison Jr, J.M., Sexton, P. and Camire, M.E. 2008. Factors influencing consumer preference of fresh potatoes varieties in Maine. American Journal of Potato Research. 85(2): 140-149.

Malaysia. 2011. Dasar Agromakanan Negara (2011-2020). Kuala Lumpur: Percetakan Nasional Malaysia Berhad. 
Malhotra, N.K., Hall, J., Shaw, M. and Oppenheim, P. 2008. Essentials of marketing research: An applied orientation ( $2^{\text {nd }}$ Edition). Frenchs Forest: Pearson Education Australia.

Martinez, M.G. and Poole, N. 2004. The development of private fresh produce safety standards: Implications for developing Mediterranean exporting countries. Food Policy 29: 229-255.

Ministry of Agriculture and Agro-Based Industry. 2012. Agrofood Statistics Book. Retrieved April 3, 2014, from http://www.moa.gov.my/web/guest/buku-perangkaanagro-makanan

Ng, R. 2011, July 14. Malaysian shoppers most price-sensitive in Southeast Asia. Retrieved April 8, from http://www.theedgemalaysia.com/media-aadvertising/189661-malaysian-shoppers-most-price-sensitive-in-southeast-asia.html

Novotorova, N.K. and Mazzocco, M.A. 2008. Consumer preferences and trade-offs for locally grown and genetically modified apples: A conjoint analysis approach. International Food and Agribusiness Management Review 11(4): 31-53.

Olson, J.C. 1977. Price as an informational cue: Effects in product evaluation. In A.G. Woodside, J.N. Sheth and P.D. Bennet (Eds.). Consumer and industrial buying behaviour. New York: North Holland Publishing Company: 267-286.

Olson, J.C. and Jacoby, J. 1972. Cues utilisation in the quality perception process. In M. Ventatesan (ed), Proceedings of The Third Annual Conference of the Association of Consumer Research, Association for Consumer Research, Iowa City: 67-79.

One potato, two potatoes. 2006. Retrived February 24, 2010 from http://kuali.com/flavours/review.asp?file=recfeature/2006/5/63onep\&sec=recfeature

Oude Ophuis, P.A.M. and van Trijp, H.C.M. 1995. Perceived quality: A market driven and consumer oriented approach. Food Quality and Preference. 6(3): 177-183.

Peri, C. 2006. The universe of food quality. Food Quality and Preference. 17(1-2): 3-8.

Pride, W., Elliot, G., Rundle-Thiele, S., Waller, D. and Paladino, A. 2004. Marketing: Core concepts and applications. Australia: John Wiley and Sons.

Rahim, H.A. 2007. Marketing of food products. In F.M. Arshad, N.R. Abdullah, B. Kaur and A.M. Abdullah (Eds). 50 years of Malaysian Agriculture: Transformational Issues and Challenges. University Putra Malaysia Press: 669-700.

Ragaert, P., Verbeke, W., Devlieghere, F. and Debevere, J. 2004. Consumer perception and choice of minimally processed vegetables and packaged fruits. Food Quality and Preference. 15(3): 259-270.

Shepherd, A.W. 2006. Quality and safety in the traditional horticultural marketing chains of Asia. AGSF Occasional Paper 13, FAO, Rome.

Steenkamp, J-B.E.M. 1990. Conceptual model of the quality perception process. J. of Business Research. 21(4): 309-333.

Toivonen, P.M. and Brummell, D.A. 2008. Biochemical bases of appearance and texture changes in fresh-cut fruit and vegetables. Postharvest Biology and Technology. 48(1): $1-14$.

Tull, D.S. and Hawkins, D.I. 1990. Marketing Research: Measurement and Method (5 ${ }^{\text {th }}$ Edition). New York: Macmillan.

van der Pol, M. and Ryan, M. 1996. Using conjoint analysis to establish consumer preferences for fruit and vegetables. British Food Journal. 98(8): 5-12.

Von Alvensleben, R. and Meier, T. 1990. The influence of origin and variety on consumer perception. Acta Horticulturae 259: 151-161. 
Table 1: Frequency of purchasing fresh potatoes

\begin{tabular}{|l|c|c|}
\hline & $\mathbf{N}$ & $\mathbf{\%}$ \\
\hline Everyday & 0 & 0.0 \\
\hline $2-3$ times per week & 8 & 3.5 \\
\hline Once a week & 55 & 24.1 \\
\hline Once every two weeks & 70 & 30.7 \\
\hline Once a month & 66 & 28.9 \\
\hline Others & 29 & 12.7 \\
\hline & & \\
\hline & 228 & 100.0 \\
\hline
\end{tabular}

Table 2: Variables respondents consider in their decision to purchase fresh potatoes

\begin{tabular}{|c|c|c|c|c|c|c|c|}
\hline & \multicolumn{5}{|c|}{ Ranking } & \multirow[t]{2}{*}{$\mathbf{N}$} & \multirow[t]{2}{*}{$\%$} \\
\hline & 1 & 2 & 3 & 4 & 5 & & \\
\hline Freshness & 73 & 39 & 11 & 6 & 2 & 131 & 58.2 \\
\hline Size & 27 & 23 & 19 & 17 & 6 & 92 & 40.9 \\
\hline Price & 22 & 25 & 19 & 12 & 11 & 89 & 39.6 \\
\hline Cleanliness & 19 & 25 & 16 & 14 & 3 & 77 & 34.2 \\
\hline Texture & 25 & 18 & 9 & 11 & 5 & 68 & 30.2 \\
\hline Skin colour & 13 & 23 & 22 & 3 & 3 & 64 & 28.4 \\
\hline Quality & 18 & 8 & 1 & 3 & & 30 & 13.3 \\
\hline No smell & 4 & 12 & 9 & 4 & & 29 & 12.9 \\
\hline Easy to peel & 3 & 3 & 6 & 4 & 5 & 21 & 9.3 \\
\hline Appearance & 6 & 7 & 3 & & 3 & 19 & 8.4 \\
\hline Origin & 2 & 1 & 4 & 6 & 6 & 19 & 8.4 \\
\hline No sprouting & 1 & 5 & 7 & 4 & 2 & 19 & 8.4 \\
\hline Type of potato/brand & 2 & 3 & 7 & 4 & 1 & 17 & 7.6 \\
\hline No holes & 1 & 5 & 4 & & & 10 & 4.4 \\
\hline Freedom from chemicals & & 2 & 4 & 2 & 2 & 10 & 4.4 \\
\hline Intended use & 3 & 3 & & 2 & 1 & 9 & 4.0 \\
\hline I can self select & 3 & & 4 & & 1 & 8 & 3.6 \\
\hline Weight of the potato & 1 & 1 & 3 & & 1 & 6 & 2.7 \\
\hline Nicely packed & 1 & & 1 & & 2 & 4 & 1.8 \\
\hline Taste & & 1 & 1 & 1 & & 3 & 1.3 \\
\hline Promotion & & 1 & & & 1 & 2 & 0.9 \\
\hline The place of purchase & 1 & & & 1 & & 2 & 0.9 \\
\hline Location - near my house/ office & & 1 & & & & 1 & 0.4 \\
\hline Halal & & & & 1 & & 1 & 0.4 \\
\hline Parking & & & & 1 & & 1 & 0.4 \\
\hline Organic & & & & 1 & & 1 & 0.4 \\
\hline & & & & & & & \\
\hline & 225 & & & & & & \\
\hline
\end{tabular}


Table 3: Importance of variables influencing respondents' decision to purchase fresh potatoes

\begin{tabular}{|l|c|c|}
\hline & Mean & SD \\
\hline Freshness & $5.61^{\mathrm{a}}$ & 0.77 \\
\hline Firmness & $5.45^{\mathrm{a}}$ & 0.77 \\
\hline Freedom from chemical residues & $5.44^{\mathrm{a}}$ & 0.93 \\
\hline Freedom from pests and diseases & $5.44^{\mathrm{a}}$ & 0.88 \\
\hline Value for money & $5.23^{\mathrm{a}}$ & 0.96 \\
\hline Freedom from sprouting & $5.15^{\mathrm{a}}$ & 1.05 \\
\hline Skin colour & $5.13^{\mathrm{a}}$ & 0.91 \\
\hline Intended use & $5.09^{\mathrm{a}}$ & 0.98 \\
\hline Competitive price & $5.09^{\mathrm{a}}$ & 1.03 \\
\hline Tuber size & $5.07^{\mathrm{a}}$ & 1.05 \\
\hline Washed & $4.94^{\mathrm{b}}$ & 1.11 \\
\hline Flesh colour & $4.93^{\mathrm{b}}$ & 1.05 \\
\hline Tuber shape & $4.85^{\mathrm{b}}$ & 1.22 \\
\hline Free from soil & $4.84^{\mathrm{b}}$ & 1.09 \\
\hline Variety & $4.62^{\mathrm{c}}$ & 1.15 \\
\hline Locally grown & $4.28^{\mathrm{d}}$ & 1.39 \\
\hline Country-of-origin & $4.24^{\mathrm{e}}$ & 1.31 \\
\hline Organic & $4.24^{\mathrm{e}}$ & 1.42 \\
\hline Depth of eyes & $4.24^{\mathrm{e}}$ & 1.34 \\
\hline Place of purchase & $4.18^{\mathrm{f}}$ & 1.43 \\
\hline Favourable prior purchase & $4.11^{\mathrm{g}}$ & 1.32 \\
\hline Availability of product information in-store & $4.02^{\mathrm{g}}$ & 1.36 \\
\hline Label or brand & $3.95^{\mathrm{g}}$ & 1.36 \\
\hline Advice from sales assistants & $3.38^{\mathrm{h}}$ & 1.43 \\
\hline Potatoes is prepacked & $3.36^{\mathrm{h}}$ & 1.40 \\
\hline Newspaper advertising/catalogues & $3.21^{\mathrm{i}}$ & 1.39 \\
\hline where i cnt ant & & \\
\hline
\end{tabular}

where 1 is "not at all important" and 6 is "very important" 
Table 4: Factors influencing respondents' decision to purchase fresh potatoes

\begin{tabular}{|c|c|c|c|c|c|}
\hline & & & actor & & \\
\hline & 1 & 2 & 3 & 4 & 5 \\
\hline $\begin{array}{l}\text { Newspaper advertising/ } \\
\text { catalogues }\end{array}$ & 0.831 & & & & \\
\hline Advice from sales assistant & 0.830 & & & & \\
\hline Potatoes is prepacked & 0.822 & & & & \\
\hline $\begin{array}{l}\text { Availability of product } \\
\text { information in-store }\end{array}$ & 0.749 & & & & \\
\hline Label or brand & 0.680 & & & & \\
\hline Organic & & 0.796 & & & \\
\hline Favourable prior purchase & & 0.697 & & & \\
\hline Country-of-origin & & 0.695 & & & \\
\hline Locally grown & & 0.656 & & & \\
\hline Variety & & 0.511 & & & \\
\hline Tuber shape & & & 0.712 & & \\
\hline Freedom from sprouting & & & 0.708 & & \\
\hline Tuber size & & & 0.685 & & \\
\hline Flesh colour & & & 0.685 & & \\
\hline Competitive price & & & & 0.805 & \\
\hline Value for money & & & & 0.752 & \\
\hline Intended use & & & & 0.734 & \\
\hline Washed & & & & & 0.815 \\
\hline Skin colour & & & & & 0.763 \\
\hline Free from soil & & & & & 0.710 \\
\hline Eigenvalue & 7.517 & 2.485 & 1.301 & 1.162 & 1.045 \\
\hline Percent variance & 18.22 & 14.67 & 12.82 & 11.27 & 10.58 \\
\hline Cumulative variance & 18.22 & 32.89 & 45.71 & 56.98 & 67.55 \\
\hline Cronbach's alpha & 0.892 & 0.837 & 0.789 & 0.785 & 0.763 \\
\hline Factor mean & $3.59^{\mathrm{c}}$ & $4.30^{\mathrm{b}}$ & $5.00^{\mathrm{a}}$ & $5.14^{\mathrm{a}}$ & $4.97^{\mathrm{a}}$ \\
\hline
\end{tabular}

